\title{
Agro-forestry Systems as a Means to Achieve Carbon Co-benefits in Nepal
}

\author{
Roshan M. Bajracharya ${ }^{1}$, Him Lal Shrestha ${ }^{1}$, Ramesh Shakya ${ }^{2}$ and Bishal K. Sitaula ${ }^{3}$ \\ ${ }^{1}$ Department of Environmental Science and Engineering, School of Science, Kathmandu University-Nepal, ${ }^{2}$ Department of Forest \\ Research and Survey, Ministry of Forest and Soil Conservation, Government of Nepal, ${ }^{3}$ Department of International Environment and \\ Development Studies, Norwegian University of Life Sciences-Norway \\ Corresponding author: rmbaj@ku.edu.np
}

\begin{abstract}
Land management regimes and forest types play an important role in the productivity and accumulation of terrestrial carbon pools. While it is commonly accepted that forests enhance carbon sequestration and conventional agriculture causes carbon depletion, the effects of agro-forestry are not well documented. This study investigated the carbon stocks in biomass and soil, along with the selected soil properties in agro-forestry plots compared to community forests (CF) and upland farms in Chitwan, Gorkha and Rasuwa districts of Central Nepal during the year 2012-2013. We determined the total above ground biomass carbon, soil organic carbon (SOC) stocks and soil properties (bulk density, organic carbon per cent, $\mathrm{pH}$, total nitrogen $(\mathrm{TN})$, available phosphorus $(\mathrm{P})$, exchangeable potassium $(\mathrm{K})$, and cation exchange capacity (CEC)) on samples taken from four replicates of $500 \mathrm{~m}^{2}$ plots each in community forests, agro-forestry systems and agricultural land. The soil was sampled in two increments at 0-15 cm and 15-30 cm depths and intact cores removed for bulk density and SOC determination, while loose samples were separately collected for the laboratory analysis of other soil properties. The mean SOC percent and corresponding soil carbon stocks to $30 \mathrm{~cm}$ depth were generally highest in CF (3.71 and 3.69 per cent, and 74.98 and $76.24 \mathrm{t} \mathrm{ha}^{-1}$, respectively), followed by leasehold forest (LHF) (2.26 and 1.13 per cent and 40.72 and $21.34 \mathrm{t} \mathrm{ha}^{-1}$, respectively) and least in the agricultural land (3.05 and 1.09 per cent, and 63.54 and $19.42 \mathrm{t} \mathrm{ha}^{-1}$, respectively). This trend was not, however, observed in Chitwan, where agriculture (AG) had the highest SOC content (1.98 per cent) and soil carbon stocks ( $42.5 \mathrm{t} \mathrm{ha}^{-1}$ ), followed by CF (1.8 per cent and $\left.41.2 \mathrm{t} \mathrm{ha}^{-1}\right)$ and leasehold forests (1.56 per cent and $\left.35.3 \mathrm{t} \mathrm{ha}^{-1}\right)$ although the differences were not statistically significant. Other soil properties were not significantly different among land use types with the exceptions of $\mathrm{pH}$, total $\mathrm{N}$, available $\mathrm{P}$ and $\mathrm{CEC}$ in the Chitwan plots. Typically, SOC and soil carbon stocks (to $30 \mathrm{~cm}$ depth) were positively correlated with each other and with TN and CEC. The AGB-C was expectantly highest in Rasuwa district CF (ranging from 107.3 to $260.3 \mathrm{t} \mathrm{ha}^{-1}$ ) due to dense growth and cool climate, followed by Gorkha (3.1 to $118.4 \mathrm{t} \mathrm{ha}^{-1}$ ), and least in Chitwan (17.6 to $95.2 \mathrm{t} \mathrm{ha}^{-1}$ ). The highest $\mathrm{C}$ stocks for agro-forestry systems in both above ground and soil were observed in Rasuwa, followed by Chitwan district. Besides forests, agro-forestry systems also hold good potential to store and accumulate carbon, hence they have scope for contributing to climate change mitigation and adaptation with co-benefits.
\end{abstract}

Key words: Above ground biomass, soil carbon stock, leasehold forest, community forest

\section{INTRODUCTION}

Agro-forestry systems are land management approaches that incorporate perennial plant species in combination with annual crops. Typically, some trees, either fruit or fodder species, are grown in and around cereal or vegetable crops on agricultural land in order to optimize and diversify production. In view of the impending climate change scenarios, agroforestry systems offer a unique opportunity to address climate change adaptation and mitigation while securing the livelihoods of the rural communities in mountain regions of Nepal (Kumar and Nair 2011; Leakey 2012;
Pachauri 2012). With the increased uncertainty of precipitation, spread of pests and diseases, and unpredictability of severe weather events, diversification and a mixed cropping approach offers a buffer against production risks. Moreover, the combination of different types of crops with varying tolerances to climate, soil, nutrient and water conditions allows for complementary and synergistic effects regarding productivity while enhancing carbon capture and storage (Montagnini and Nair 2004; Akinnifesi et al. 2009; Garrity 2012). 
While forests are regarded as the best means for enhancing carbon capture and sequestration in terrestrial ecosystems (Ranabhat et al. 2000; Lal 2005; Bhattarai et al. 2012; Dahal and Kafle 2013), agro-forestry also offers potential for carbon accumulation while also providing income and livelihood benefits (Regmi 2003; Khanal 2011; Kumar and Nair 2011). Neupane et al. (2002) noted that the farmers were likely to adopt agroforestry practices if they kept high numbers of livestock such as goats and cattle. This finding was supported by Regmi (2003) who observed that agro-forestry improved farm household livelihoods by providing fodder self-sufficiency for livestock through which income was augmented. Pandit et al. (2014) observed that cultivation of agro-forestry species including medicinal plants on private land in Kavre district of Central Nepal led to economic benefits and livelihood security for farmers. Likewise, in Liberia, Fouladbash and Currie (2015) noted that agro-forestry practices provided income diversification and enhanced food security thus offering local people an improved climate change adaptive capacity.

Farming on hill slopes poses problems related to soil erosion, water availability and microclimatic variability. Slope areas often tend to have shallow, and less developed soils with low nutrient and water retention characteristics. Also, such lands are subject to excessive and uncontrolled runoff during heavy rain events leading to severe soil erosion and land degradation. Thus, the use of these sloping lands have traditionally been contingent upon the application of conservation practices to prevent their degradation, such as, terracing, ditches for safe water disposal, vegetative or non-living barriers to prevent uncontrolled overland flow of water or to trap eroded sediment. Apart from physical or structural measures to conserve soil and water in order to prevent land degradation, cropping patterns and combinations of plant types can also serve as an effective approach to achieve conservation goals while simultaneously enhancing productivity and improving rural livelihoods (Tacio 1993; Nuberg et al. 2009). In this respect, agro-forestry systems hold considerable promise for enabling multiple benefits to farming communities in the hill areas of Nepal (The Glacier Trust 2011; Synnot 2012).

Acharya and Kafle (2009) pointed out that agro-forestry practices such as planting of multipurpose trees on farm land helps to reduce land degradation on steep slopes in the hills of Nepal. Moreover, these practices offer other benefits like biodiversity conservation, soil improvement, nutrient cycling and carbon sequestration (Khanal 2011; Obeng and Aguilar 2015). Yadav et al. (2010) found that under tree-based traditional agro-forestry systems in Rajasthan, India, soil biological activity increased significantly leading to enhanced microbial biomass carbon, nitrogen and phosphorus. Similar results of significantly higher soil organic carbon (SOC), nitrogen $(\mathrm{N})$, phosphorus $(\mathrm{P})$, potassium $(\mathrm{K})$ mean weight and diameter of soil aggregates and microbial biomass carbon were reported by Ramesh et al. (2013) under 26 year old multipurpose trees in Meghalaya, India, compared to control plots with no trees. Pandit et al. (2012) estimated that for agro-forestry systems in Rasuwa district, 48.6 tons carbon were accrued over 20 years providing good potential for climate change mitigation and carbon trading benefits to local farmers.

In view of the influence of land use and forest management types on carbon stocks in the terrestrial ecosystems, this study was carried out to assess the effect of agro-forestry systems on total biomass and soil carbon stocks as well as other selected soil properties compared to community forests and conventional upland agriculture in central Nepal. 


\section{嗮 \\ METHODS \\ Study Area}

Three watersheds in Gorkha, Chitwan and Rasuwa districts of Nepal were selected for the study (Figure 1). The three study sites were located in 3 different eco-regions among the 200 Global eco-regions. Betrawati watershed of Rasuwa district represents the temperate forest at higher altitudes (1500-1600 m) within the Middle Mountains region. Ludikhola
Bajracharya et al. watershed of Gorkha district represents the mixed hill Sal (Shorea robusta) forest of the lower mid-hills ranging in altitude from 900$1000 \mathrm{~m}$. Kayarkhola watershed of Chitwan district comprises of the low altitude (200-300 m) forest of the foot hills of Nepal dominated by Shorea robusta and associated species. Community forests within each watershed were selected for comparison with agroforestry and agricultural land use systems.

\section{Location Map of Study Area}
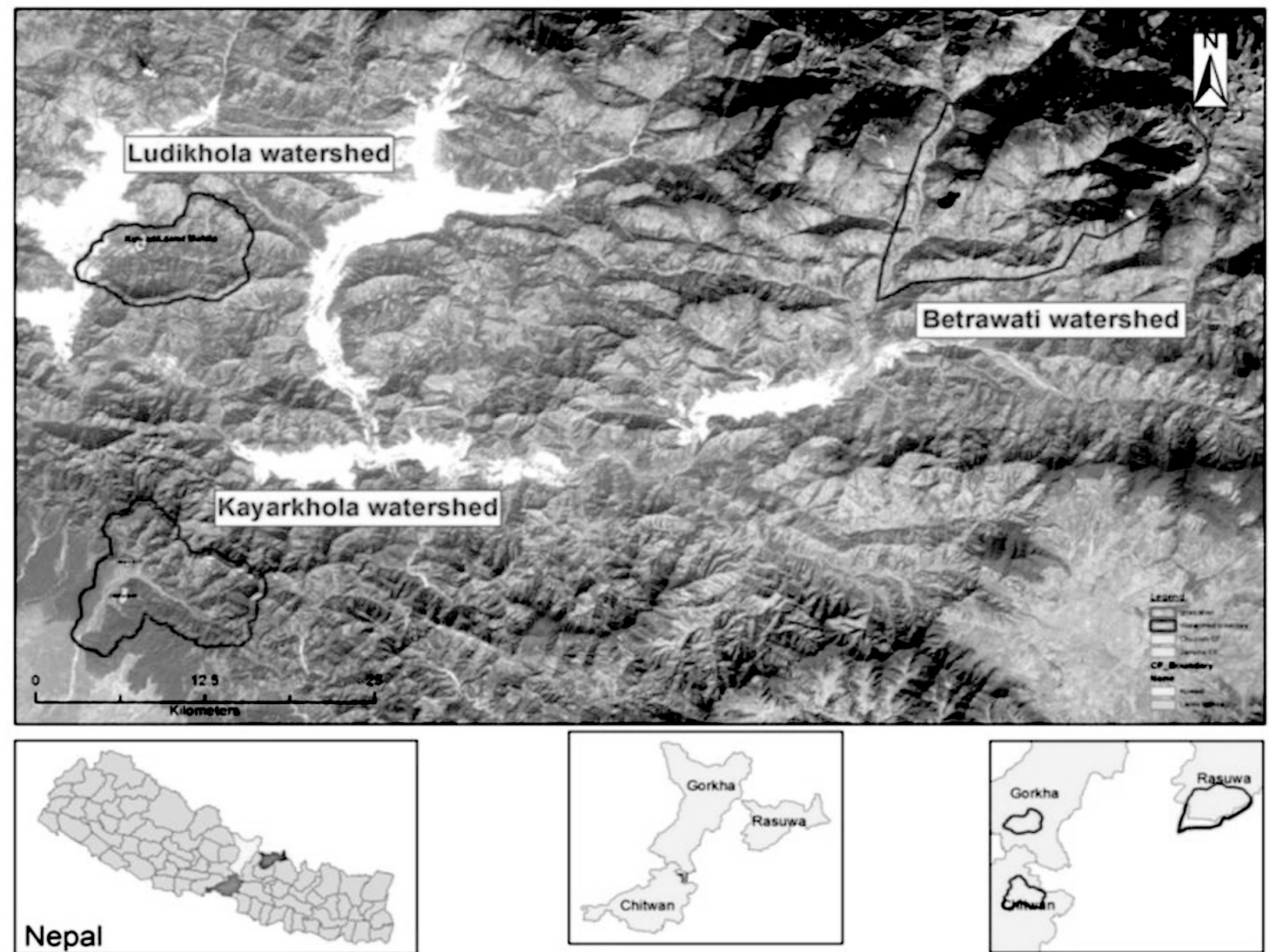

Figure 1. Map Showing the Location of the Study Watersheds in Central Nepal 


\section{Carbon Stock Quantification}

\section{Field Sampling and Measurement}

For the sampling of biomass and soil carbon, random sampling was carried out in four replicate plots in each of the three land management types, namely, Community Forests, agro-forest and agricultural land. The biomass and soil sampling was done from autumn 2012 to spring 2013, and subsequent carbon stock calculations were done using standard methods commonly used as described below.

\section{Above Ground Tree Biomass}

The diameter at breast height (DBH) of $1.3 \mathrm{~m}$ along with the height of all trees having $\mathrm{DBH}$ greater than $0.1 \mathrm{~m}$ were measured by using a diameter-tape and clinometer, respectively, in a randomly laid-out concentric forest plots of $500 \mathrm{~m}^{2}$ area by delineating a circle of $12.56 \mathrm{~m}$ radius. For the general characteristics of the plot, crown density was also measured using a densitometer. The allometric equation as suggested by Chave et al. (2005) was used for Above Ground Tree Biomass (AGTB) calculation as the study areas do not lie in the heavy rainfall region. Allometric equations are established in a purely empirical way on the basis of exact measurements from a relatively large sample of typical trees (Hairiah et al. 2010). The AGTB (in $\mathrm{t} \mathrm{ha}^{-1}$ ) was calculated using DBH (in cm), height (in $\mathrm{m}$ ) and woodspecific gravity (in $\mathrm{g} / \mathrm{cm}^{3}$ ) of the trees according to equation 1 below:

$\mathrm{AGTB}=0.059 * \delta \mathrm{D} 2 \mathrm{H}$

Where,

$\delta=$ wood specific gravity $\left(\mathrm{g} \mathrm{cm}^{-3}\right)$

$\mathrm{D}=$ tree diameter at breast height $(\mathrm{cm})$

$\mathrm{H}=$ height of the tree (m)
Leaf-litter, Herbs and Grass Biomass

To get the Leaf-litter, Herbs and Grass Biomass (LHGB), all the litter (dead leaves, twigs, and so forth) within the $1 \mathrm{~m}^{2}$ sub-plots are collected and weighed. Approximately $100 \mathrm{~g}$ of evenly mixed sub-samples were brought to the laboratory to determine their moisture contents, from which total dry mass was calculated. Likewise, herbs and grass (all non woody plants) within the plots are collected by clipping all the vegetation down to ground level, weighing them, placing in the weighing bag sample and bringing them to the laboratory to determine the oven dry weight of the biomass.

For the forest floor (herbs, grass, and litter), the amount of biomass per unit area is given by equation 2 (Chave et al. 2005) below:

LHGB $=\frac{\text { Wfield }}{A} \cdot \frac{\text { Wsubsample dry }}{\text { Wsubsample wet }} \times 1000 \ldots(2)$ Where,

LHG $=$ biomass of leaf-litter, herbs and grass $\left[\mathrm{t} \mathrm{ha}^{-1}\right]$;

$\mathrm{W}_{\text {field }}=$ weight of the fresh field sample of leaf litter, herbs, and grass, destructively sampled within an area of size A (gm);

$\mathrm{W}_{\text {subsample wet }}=$ weight of the fresh sub-sample of leaf litter, herbs, and grass taken to the laboratory to determine moisture content (gm)

$\mathrm{W}_{\text {subsample dry }}=$ weight of the oven dried subsample of leaf litter, herbs, and grass (gm)

The carbon contents in both AGTB and LHGB were calculated by multiplying LHGB with the IPCC (2006) default carbon fraction of 0.47 .

\section{Below-ground Biomass}

Below-ground biomass (BGB) estimation is much more difficult and time consuming than estimating above-ground biomass. Destructive 
sampling of the plots to determine BGB was not possible. Hence, as an approximation, the recommended root-to-shoot ratio value of 1:5 was used as recommended by MacDicken (1997).

\section{Soil Organic Carbon}

The soil samples were collected from the center of each demarcated plot in the forest and agro-forestry plots. They were taken randomly from the agriculture fields at depth ranges of $0-15 \mathrm{~cm}, 15-30 \mathrm{~cm}, 30-60 \mathrm{~cm}$ and $60-100 \mathrm{~cm}$ or until bed rock was encountered. Core samples extracted using a steel ring and corer of $4.7 \mathrm{~cm}$ diameter and $6 \mathrm{~cm}$ height were used for determination of the bulk density (according to Blake and Hartge 1986) and SOC, while other properties were determined using loose soil samples. The samples were sealed in plastic bags, transported to the laboratory, and oven dried (at $105^{\circ} \mathrm{C}$ ) until a constant weight was gained to determine their water content. The percent carbon content of soils was determined using the loss-on-ignition (dry combustion) method as described in Neslon and Sommers (1982).

The carbon stock density of SOC was calculated according to Pearson et al. (2007):

$\mathrm{SOC}=\partial^{*} \mathrm{~d}^{*}$ per cent $\mathrm{C} \ldots \ldots \ldots \ldots \ldots \ldots \ldots \ldots \ldots$

Where,

$\mathrm{SOC}=$ soil organic carbon stock per unit area $\left[\mathrm{t} \mathrm{ha}^{-1}\right]$,

$\partial=$ soil bulk density $\left[\mathrm{g} \mathrm{cm}^{-3}\right]$,

$\mathrm{d}=$ the total depth at which the sample was taken $[\mathrm{cm}]$, and per cent $\mathrm{C}=$ carbon concentration [ per cent].

\section{Total Carbon Stock Density}

To determine the overall carbon stocks in a given forest, the calculated per plot AGTB was multiplied by the total area in hectares of the forest and expressed as tons of carbon per hectare. Similarly, the carbon content in $\mathrm{BGB}$ was then calculated by multiplying above-ground biomass carbon by 0.2 (for the root shoot ratio) and also extrapolated to the entire area of the forest and expressed in tons per hectare. Likewise, the LHGB weights were subsequently converted into tonnes of carbon per ha for each land use type and SOC also extrapolated to the tonnes of carbon per ha by summing up the depth-wise carbon stocks. The total carbon stock density for a given land use type was then determined as the sum of the AGTB, BGB, LHGB and SOC for that land use. The calculations were done according to commonly used methods as given by Hairiah et al. (2010), IPCC (2006) and Chave et al. (2005).

\section{Baseline Soil Properties}

Other general baseline soil properties including soil texture, $\mathrm{pH}$, total $\mathrm{N}$, available $P$, exchangeable $K$ and Cation Exchange Capacity (CEC) were determined using standard methods as given in the Methods of Soil Analysis (USDA Monograph No. 9). The soil texture, that is, particle size distribution, was determined using the soil hydrometer method (Gee and Bauder 1986), while soil reaction was measured using a glass-calomel probe with digital $\mathrm{pH}$ meter in a 1:1 soil:water mixture (McLean 1982). Total $\mathrm{N}$ of the soil samples were determined using the Kjeldahl method (Bremner and Mulvaney 1982), available $\mathrm{P}$ by a modified Olsen method (Olsen and Sommers 1982), exchangeable K by ammonium acetate extraction (Knudsen et al. 1982), and CEC by ammonium acetate/ potassium chloride extraction (Rhodes 1982).

\section{RESULTS AND DISCUSSION}

The soils at the study locations varied in texture from sandy loam in Gorkha district to silty clay and sandy clay in Chitwan district. Despite of a wide variation in textural classes, most of the soils belonged to the silt loam, silty clay loam and clay loam classes across all districts (data not shown). A notable trend 
was, however, the agricultural soils in all three districts were higher in clay, being mostly silty clay loams and sandy clay loams while the soils in forested areas tended to be of lighter texture, namely, loam, sandy loam or silty loam. The fact that agricultural soils were of higher clay content was likely due to the selection of upland farm (e.g., bari) soils which generally had eroded top soils and exposed subsoils with higher clay contents. On the other hand, forested areas with leaf litter and ground vegetation cover usually have higher water infiltration and percolation leading to leaching of clay particles down to subsurface layers. Soils in the lower foothills and valleys of Chitwan were more developed, hence generally are called Alfisols, whereas, those of Rasuwa district above $1500 \mathrm{~m}$ were less weathered with fewer developmental features, thus, typically Inceptisols. The soils studied in Gorkha district were intermediate to those in Chitwan and Rasuwa.
The SOC contents were generally highest in $\mathrm{CF}$ for all the three districts as seen from Figure 2. Agro-forestry systems (e.g., leasehold forest (LHF)) did not have consistently high SOC per cent, however, in Rasuwa district values were comparable with CF. Other workers have also noted that forest soils tend to have high SOC, especially in the topsoil (Shrestha et al. 2004; Lal 2005; Dahal and Kafle 2013). Agricultural land has similar SOC contents to that of leasehold agro-forestry with the exception of Rasuwa district. It should be noted, however, that SOC was statistically and significantly different only in Gorkha district (Table 1) owing presumably to a high variability of the data.

Soil bulk density (BD) was not significantly different among districts (Table 2) although there was an observed trend of somewhat higher values in Chitwan district likely due to a combination of low organic matter levels and coarse-sandy textured soils (Figure 2).

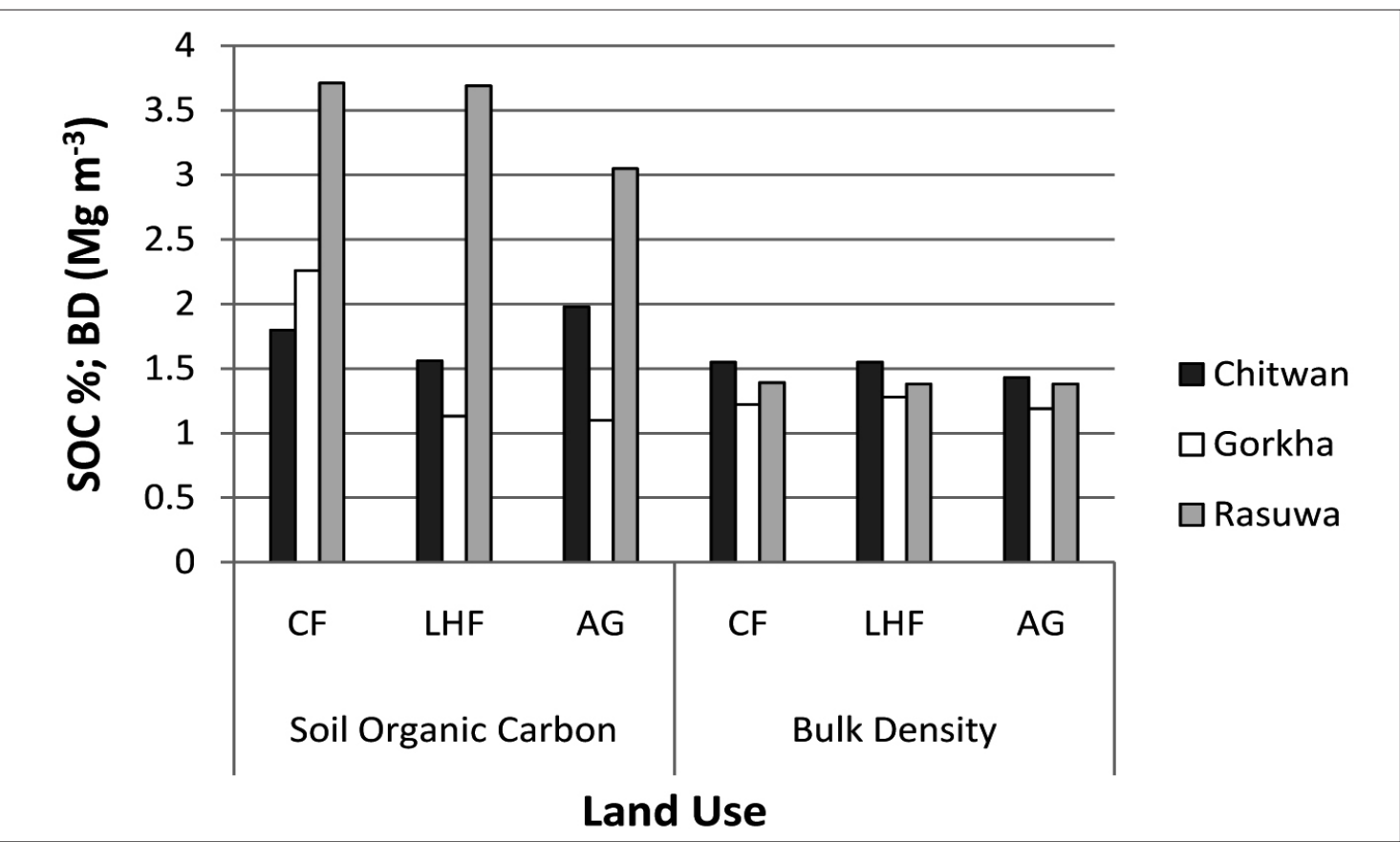

Figure 2. Mean Values of SOC per cent and Bulk Density for Three Land Uses in the Study Districts

$\mathrm{CF}=$ Community Forest, $\mathrm{LHF}=$ Lease-hold Agro-forest, $\mathrm{AG}=$ Agricultural Land 


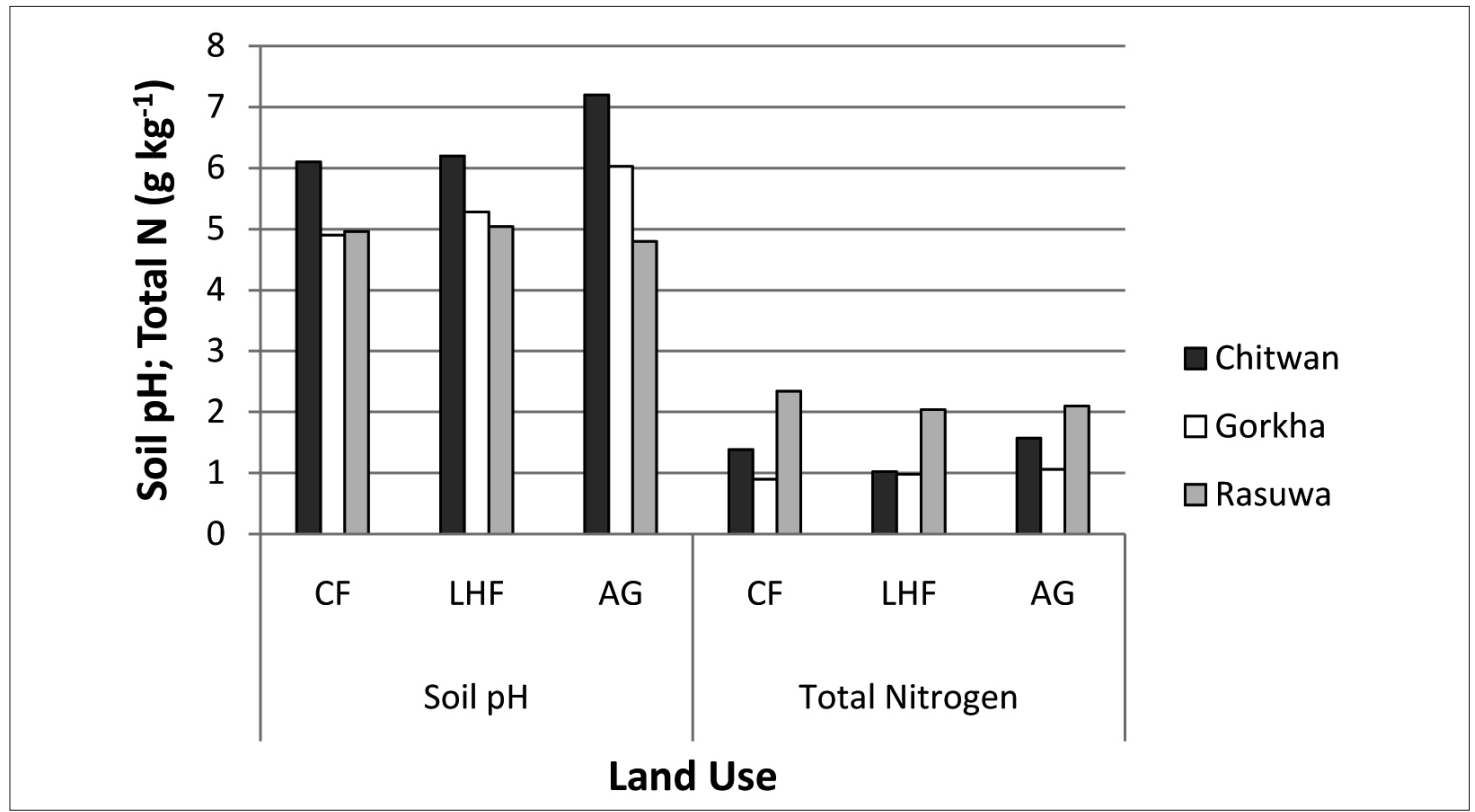

Figure 3. Mean Values of Soil pH and Total Nitrogen in Three Land Uses of the Three Study Districts

CF = Community Forest, LHF = Lease-hold Agro-forest, AG = Agricultural Land

The soils were mostly slightly acidic to strongly acidic with the exception of agricultural land in Chitwan district, which was neutral (Figure 3). Soil pH differed significantly among land use types in Chitwan and Gorkha but not in Rasuwa district (Table 1). The higher $\mathrm{pH}$ values in agricultural land in Chitwan and Gorkha could be attributed to the application of agricultural lime. The status of soil $\mathrm{pH}$ and nutrients tends to be influenced either by geology and parent material or by the application of fertilizers and lime by farmers (Atreya et al. 2008; Bajracharya and Sherchan 2009). While the rocks and parent materials leading to soil formation in the hills generally tend to be acidic, deposits in the lowland areas may be less acidic or near neutral. On agricultural land, however, the application of amendments such as fertilizers can lead to increased acidity, while application of lime increases the $\mathrm{pH}$ of soils.

Total $\mathrm{N}$ followed a trend similar to that of SOC per cent with highest values in Rasuwa district and not statistically non-significant differences among land use types (Figure 3, Table 1). This is evident by a high correlation between SOC and total $\mathrm{N}$ as seen in Table 2. 


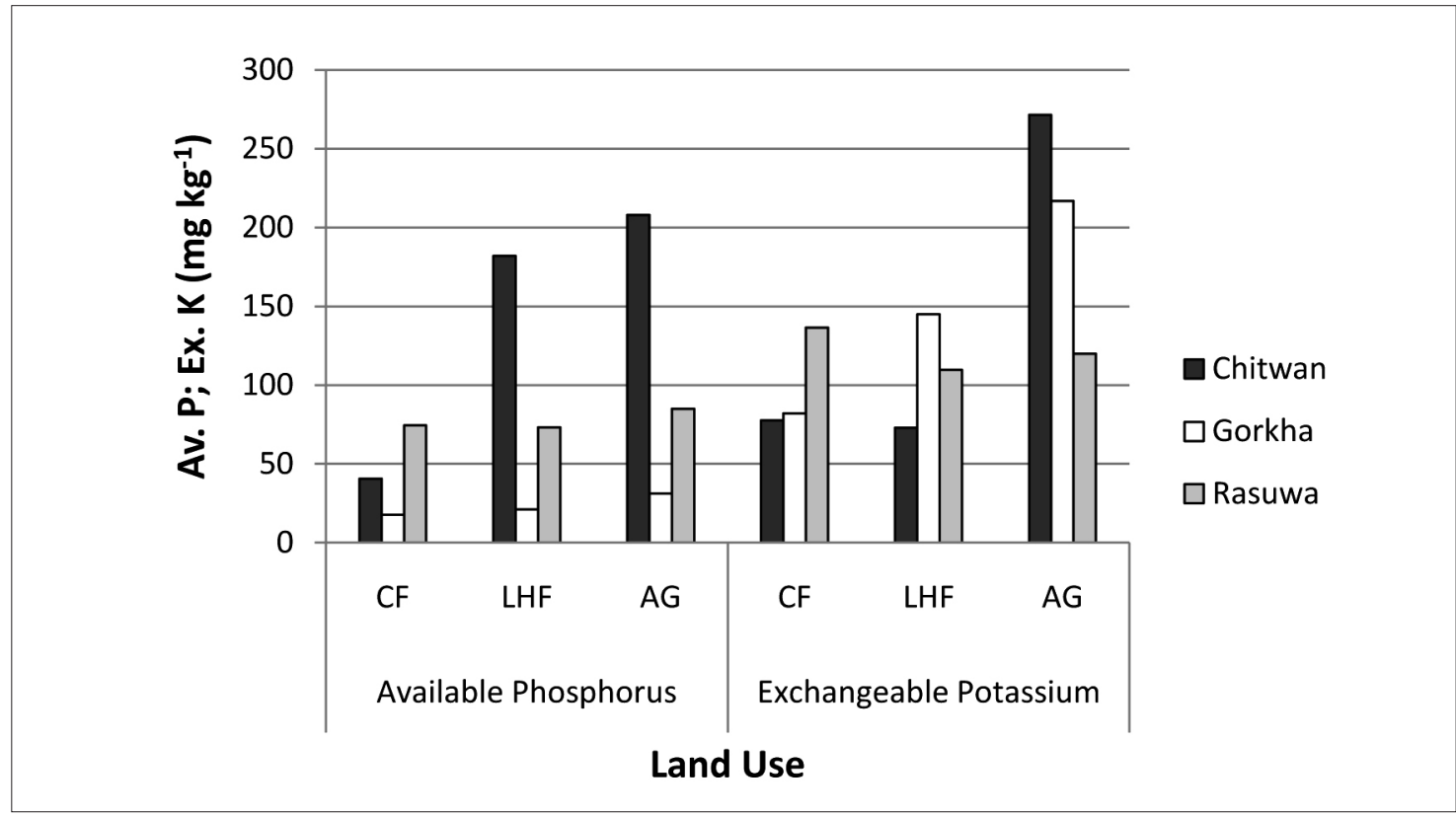

Figure 4. Mean Values of Available P and Exchangeable $\mathrm{K}$ in Three Land Use types of the Study Districts

CF $=$ Community Forest, LHF $=$ Lease-hold Agro-forest, AG $=$ Agricultural Land

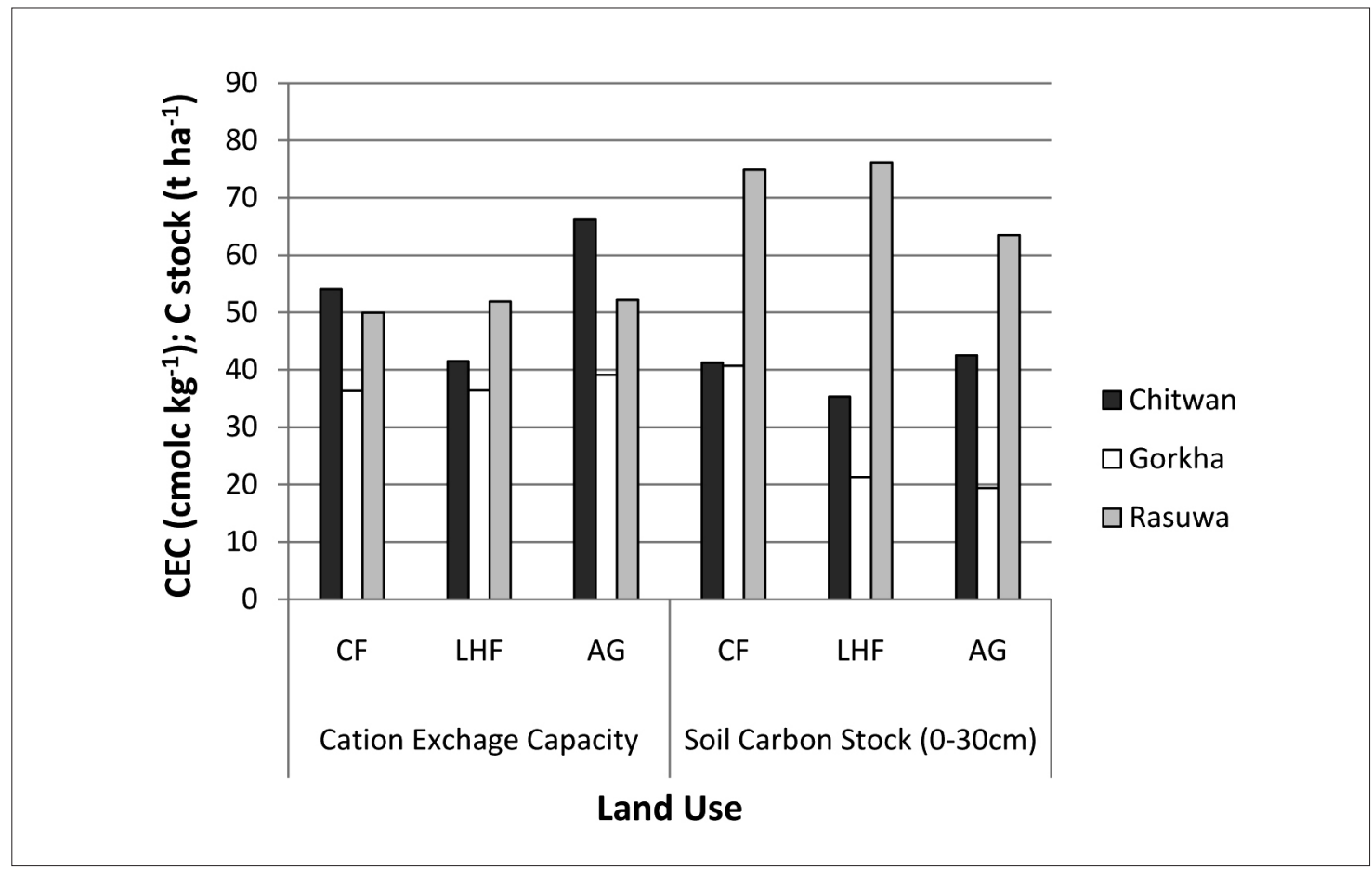

Figure 5. Mean CEC and Soil Carbon Stocks in Three Land Uses of the Study Districts CF $=$ Community Forest, LHF $=$ Lease-hold Agro-forest, AG $=$ Agricultural Land 
The plant available $\mathrm{P}$ was significantly higher in agro-forestry systems and agricultural land only in Chitwan district (Figure 4 and Table 1). Likewise, exchangeable $\mathrm{K}$ was highest in agricultural lands in all districts although no statistical significance was observed due to high variability of data. This trend was thought to be the consequence of $\mathrm{P}$ and $\mathrm{K}$ fertilizer applications on agricultural land and to a lesser extent in agro-forestry systems.
The CEC of soils did not follow any clear trend (Figure 5) and was generally not statistically or significantly different among land uses except in Chitwan district (Table 1). Nonetheless, CEC was highly correlated with SOC and soil chemical parameters, namely, $\mathrm{pH}$ and total $\mathrm{N}$ (Table 2). The soil carbon stock to $30 \mathrm{~cm}$ depth expectantly followed a similar trend to that of SOC per cent (Figure 5) and was also highly correlated with SOC, total N, and CEC (Table 2).

Table 1. One-way Analysis of Variance of Soil Properties According to Land Use for Each District (Agro-ecological Zone), ( $\mathrm{N}=24)$

\begin{tabular}{lllllll}
\hline & Chitwan & & Gorkha & & Rasuwa \\
\hline Soil Property & F-test value & Signif. & F-test value & Signif. & F-test value & Signif. \\
\hline SOC per cent & 0.89 & $\mathrm{~ns}$ & 12.92 & $* * *$ & 1.66 & $\mathrm{~ns}$ \\
Bulk density & 1.32 & $\mathrm{~ns}$ & 0.81 & $\mathrm{~ns}$ & 0.01 & $\mathrm{~ns}$ \\
Soil pH & 11.86 & $* * *$ & 6.85 & $* *$ & 2.41 & $\mathrm{~ns}$ \\
Total N & 4.12 & $*$ & 0.24 & $\mathrm{~ns}$ & 0.72 & $\mathrm{~ns}$ \\
Avail. P & 45.54 & $* * *$ & 1.93 & $\mathrm{~ns}$ & 0.20 & $\mathrm{~ns}$ \\
Exch. K & 2.08 & $*$ & 1.79 & $\mathrm{~ns}$ & 0.60 & $\mathrm{~ns}$ \\
CEC & 7.38 & $* *$ & 1.07 & $\mathrm{~ns}$ & 0.14 & $\mathrm{~ns}$ \\
C-Stock & 0.59 & $\mathrm{~ns}$ & 15.28 & $* * *$ & 1.63 & $\mathrm{~ns}$ \\
\hline
\end{tabular}

Note: *,**,*** indicate significance at $0.05,0.01$ and 0.001 level of $\mathrm{P}$, respectively 
Table 2. Peason's Correlation Matrix for Soil Properties Across all Three Districts $(\mathbf{N}=72)$

\begin{tabular}{|c|c|c|c|c|c|c|c|}
\hline & BD & C-stock & $\mathrm{pH}$ & TN & AP & EK & CEC \\
\hline SOC & -0.77 & $0.96 * * *$ & $-0.39 * *$ & $0.75^{* * *}$ & 0.03 & -0.03 & $0.36^{* *}$ \\
\hline $\mathrm{BD}$ & & 0.16 & $0.24 *$ & 0.05 & $0.37 * *$ & -0.19 & 0.13 \\
\hline C-stock & & & $-0.34 * *$ & $0.77 * * *$ & 0.10 & -0.07 & $0.42^{* * *}$ \\
\hline $\mathrm{pH}$ & & & & -0.14 & $0.52^{* * *}$ & $0.34^{* *}$ & $0.26^{* *}$ \\
\hline TN & & & & & 0.18 & 0.09 & $0.39 * *$ \\
\hline $\mathrm{AP}$ & & & & & & 0.09 & $0.29 *$ \\
\hline EK & & & & & & & $0.21 \dagger$ \\
\hline
\end{tabular}

Note: $†$ indicates $\mathrm{P}<0.10$; * indicates $\mathrm{P}<0.05$; ** indicates $\mathrm{P}<0.01$; and, *** indicates $\mathrm{P}, 0.001$

When considering the total above and below ground carbon stocks, including biomass and SOC, clearly, CF had the highest total carbon stocks for all of the three districts as shown in Figure 6. However, in Chitwan and Rasuwa districts, leasehold agro-forestry systems also had considerable total carbon stocks in the range of 150 to $360 \mathrm{t} \mathrm{ha}^{-1}$. However, for agricultural land uses, the total carbon stocks reflected only the SOC, and hence were substantially lower than the other land uses (Figure 6). Nonetheless, total carbon stocks significantly differed statistically only for land uses in Gorkha district (Table 1), while they were not significantly different in Chitwan and Rasuwa, presumably due to high variability within replicate plots. Expectantly, the total carbon stocks were highly positively correlated with SOC content, total $\mathrm{N}$ and CEC as indicated by Pearson's correlation coefficients in Table 2.

The SOC contents and soil carbon stocks were generally higher in community forests and leasehold forests. The results are corroborated by other studies which also indicated higher SOC in forests, particularly in the topsoil (Bajracharya et al. 2004; 2006; Dahal and Kafle 2013). However, upland agricultural soils may also have high SOC contents and stocks due to the application of large amounts of farmyard manure and the relatively deep soils found in these farms (Shrestha et al. 2004; Bajracharya et al. 2009).

High carbon stocks and sequestration potential of forest land have been well documented by numerous researchers (Lal 2005; Bhattarai et al. 2012; Jati 2012; Dahal and Kafle 2013). The high SOC and biomass carbon observed in Rasuwa for all land use types was attributed to the high elevation (1700-1800m) with cool climate and slow decomposition rates. Agro-forestry systems also had total carbon stocks comparable to CF (with the exception of Gorkha district) indicating potential for climate change mitigation. Also, due to multiple benefits and diversification of crops, LHF potentially offers better adaptive capacity to climate change as noted by other workers (Neupane et al. 2001; Zomer et al. 2007; Garrity 2012). Moreover, agro-forestry can lead to enhanced livelihoods of farmers when combined with high-value crops, Medicinal Aromatic Plants (MAPs), and livestock (Thorne and Tanner 2002; Regmi 2003; Nuberg et al. 2009). 

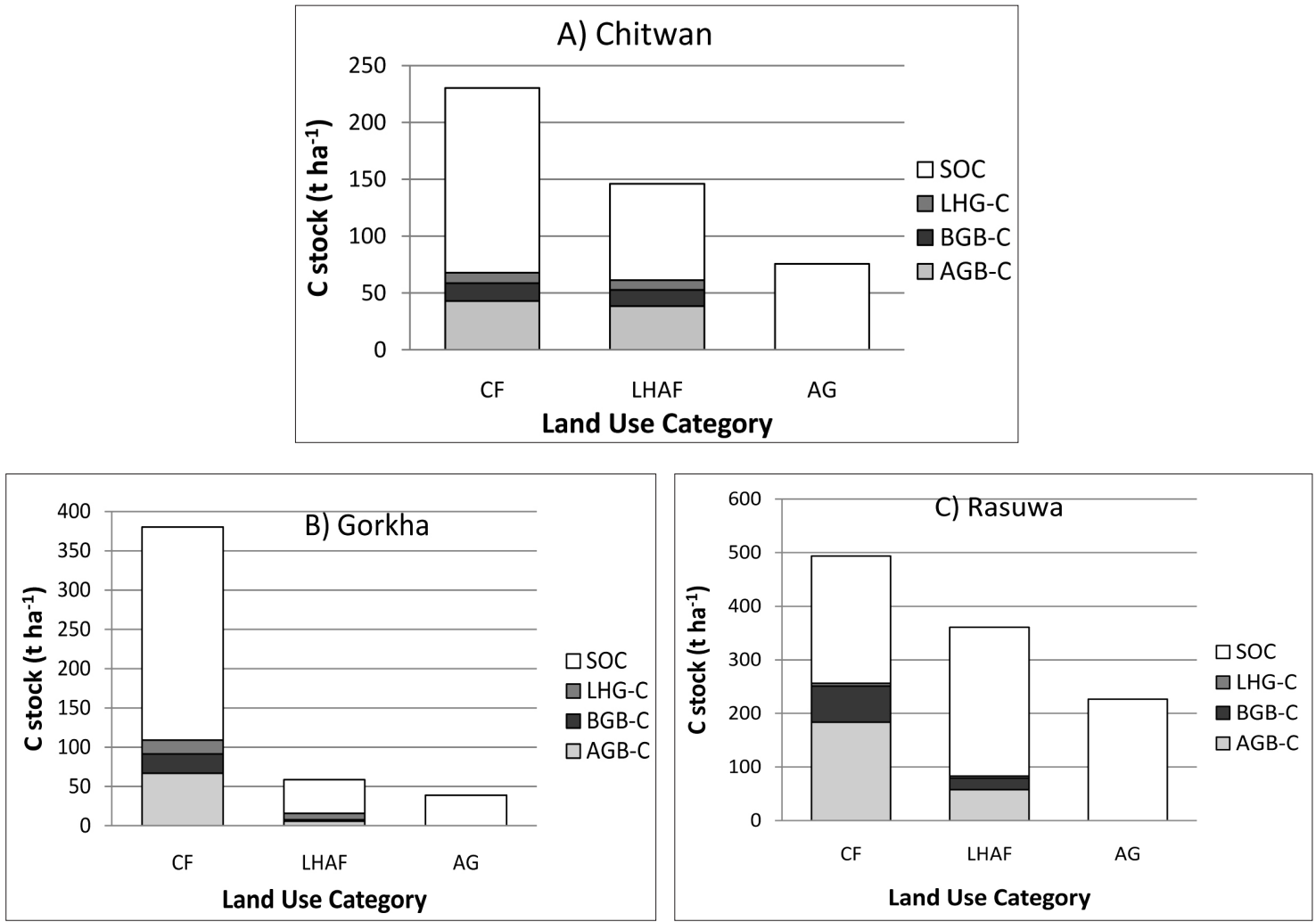

Figure 6. Total Carbon Stocks for Three Land Use Types in A) Chitwan, B) Gorkha, and C) Rasuwa districts.

CF $=$ Community Forest, LHAF $=$ Lease-hold Agro-forest, AG = Agricultural Land, SOC = Soil Organic Carbon, LHG-C = Leaf-litter, Herb \& Grass Carbon, BGB-C = Below-ground Biomass Carbon, and AGB-C = Above-ground Biomass Carbon.

\section{SUMMARY AND CONCLUSIONS}

From the above results, it can be inferred that the SOC contents and soil carbon stocks were generally higher with elevation apparently due to the cool moist climate and slow organic matter decomposition rates. While the total carbon stocks were higher in all three districts under CF land use, carbon stocks for leasehold agro-forestry was also comparable. The soil carbon stock was significantly positively correlated with SOC per cent, total $\mathrm{N}$ and CEC, whereas, the SOC per cent was correlated positively with total N, CEC, and negatively with soil $\mathrm{pH}$. The soil $\mathrm{pH}$ was also significantly positively correlated with the available $\mathrm{P}$, exchangeable $\mathrm{K}$ and CEC.
Above-ground and below-ground biomass carbon followed similar trends as SOC stock with Rasuwa district having the highest values. The order of total carbon stock for the three land use types was: $\mathrm{CF}>\mathrm{LHF}>\mathrm{AG}$. Thus, agro-forestry systems have higher total carbon stocks than conventional agriculture, and in cool agro-ecological zones, the SOC and total carbon stocks of LHF are comparable with other forests.

Hence, due to multiple benefits and diversification of crops leading to enhanced incomes and livelihoods, it can be said that agro-forestry systems potentially offers 
better adaptive capacity for local farming communities to climate change along with mitigation and carbon trading possibilities. Targeted policy initiatives are required to promote sustainable land management alternatives such as diversified agro-forestry practices, particularly in the hills of Nepal. Further work in different east-west regions across the Himalaya is needed to verify the carbon sequestration potential and livelihood benefits of these systems.

\section{REFERENCES}

Acharya, A.K. and Kafle, N. 2009. Land Degradation Issues in Nepal and its Management through Agro-forestry. Journal of Agriculture and Environment, 10: 115-123.

Akinnifesi, F.K., Muys, B. and Ajayi, O.C. 2009. Africa Needs Agro-forestry to Cut Forest Emissions. SciDev.Net, 8 July, 2009. (http:/ / email. scidev.net/t/26320/4570866/4845/0/ accessed on 15 July, 2009).

Atreya, K., Sharma, S., Bajracharya, R.M. and Rajbhandari, N.P. 2008. Developing a Sustainable Agro-System for Central Nepal Using Reduced Tillage and Straw Mulching. Journal of Environmental Management, 88(3): 547-555.

Bajracharya, R.M. and Sherchan, D.P. 2009. Fertility Status and Dynamics of Soils in the Nepal Himalaya: A Review and Analysis. New York: Nova Publishers.

Bajracharya, R.M., Sharma, S., Dahal, B.M., Sitaula. B.K. and Jeng, A. 2006. Assessment of Soil Quality Using Physiochemical and Biological Indicators in a Mid-Hill Watershed of Nepal. Paper Presented at the International Seminar on Environmental and Social Impacts of Agricultural Intensification in Himalayan Watersheds, Oct. 1517, 2006, Nagarkot, Nepal.

Bajracharya, R.M., Sitaula, B.K., Shrestha, B.M., Awasthi, K.D., Balla, M.K. and Singh B.R. 2004. Soil Organic Carbon Status and Dynamics in the Central Nepal Middle Mountains. Journal of the Institute of Forestry, 12: 28-44.

Bhattarai, T.P., Skutsch, M., Midmore, D. and Rana, E. B. 2012. The Carbon Sequestration of Community Based Forest Management in Nepal. Journal of Climate Change, 3(2): 234-253.

Blake, G.R. and Hartge, K.H. 1986. Bulk Density. In: A.L. Page (Ed.), Methods of Soil Analysis, Part

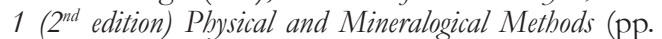
363-376), American Society of Agronomy Monograph, 9. Madison, WI, USA.
Bremner, J.M. and Mulvaney, C.S. 1982. Nitrogen Total. In: A. L. Page, R. M. Miller and D. R. Keeney, (Eds.), Methods of Soil Analysis Part 2 (2nd edition) Chemical and Microbiological Properties (pp. 595-610), American Society Agronomy Monograph, 9. Madison, WI, USA.

Chave, J., Andalo, C., Brown, S., Cairns, M. A., Chambers, J. Q. and Eamus, D. 2005. Tree Allometry and Improved Estimation of Carbon Stocks. Oecologia, 45: 87-99.

Dahal, K. N. and Kafle, G. 2013. Organic Carbon in Soil and Biomass of an AlnusNepalensis Forest in Kathmandu, Nepal. International Journal of Agriculture and Forestry, 3(6): 240-243.

Fouladbash, L. and Currie, W.S. 2015. Agroforesty in Liberia: Household Practices, Perceptions and Livelihood Benefits. Agro-forestry Systems, 89: 247 266.

Garrity, D. 2012. Agro-forestry and the Future of Global Land Use. Pp. 21-30. In: P.K.R. Nair and D. Garrity (Eds.), Agro-forestry - The Future of Global Land Use. Advances in Agro-forestry, 9: 21-30.

Gee, G.W. and Bauder, J.W. 1986. Particle Size Analysis. In: A. Klute (Ed.), Methods of Soil Analysis, Part 1 (2ndedition) Physical and Mineralogical Methods (pp. 383-411), American Society of Agronomy Monograph, 9. Madison, WI, USA.

Hairiah, K., Dewi, S., Agus, F., Velarde, S., Ekadinata, A., Rahayu, S. and van Noordwijk, M. 2010. Measuring Carbon Stocks Across Land Use Systems: A Manual. World Agro-forestry Centre, Bogor, Indonesia.

IPCC. 2006. Good Practice Guidance for National Greenhouse Gas Inventories. Agriculture, Forestry, and Other Land Uses (AFOLU). Geneva, Switzerland: Intergovernmental Panel on Climate Change.

Jati, R. 2012. Comparative Study of Carbon Assessment: A Case Studyin Kumvakarna Conservation Community forest, GhunsaLelep VDC, Taplejung district. MSc Thesis, Khowpa Engineering College, Nepal.

Knudsen, D., Peterson, G.A. and Pratt, P.F. 1982. Potassium. In: A. L. Miller, R. H. Keeney and D.R. (Eds.), Methods of Soil Analysis Part 2 (2nd edition), Chemical and Microbiological Properties (225-246). Madison, USA.

Khanal, S. 2011. Contribution of Agro-forestry in Biodiversity Conservation and Rural Needs Fulfillment: A Case Study from Kaski District. Pokhara, Nepal. Master's Thesis, Institute of Forestry, Tribhuvan University, Nepal.

Kumar, B. M. and Nair, P.K.R. (Eds.). 2011. Advances in Agro-forestry: Carbon Sequestration Potential of Agro- 
forestry Systems- Opportunities and Challenges (Vol. 8). Dordrecht - Heidelberg - London- New York: Springer.

Lal, R. 2005. Forest Soils and Carbon Sequestration. Forest Ecology and Management, 220 (1-3): 242-258.

Leakey, R. 2012. Environmental Resilience and Agroforestry. In: P.K.R. Nair and D. Garrity (Eds.), Agro-forestry - The Future of Global Land Use (pp 1112). Springer Science and Business Media.

MacDicken, K. G. 1997. A Guide to Monitoring Carbon Storage in Forestry and Agro-Forestry Projects. Arlington, USA: Winrock International.

McLean, E.O. 1982. Soil pH and Lime Requirement. Methods of Soil Analysis. Part 2 (2 $2^{\text {nd }}$ edition) Chemical and Microbiological Properties. American Society of Agronomy, $\mathbf{9}$.

Montagnini, F. and Nair, P.K.R. 2004. Carbon Sequestration: An Underexploited Environmental Benefit of Agro-forestry Systems. Agro-forestry Systems, 61: 281-295.

Nelson, D.W., and Sommers, L.E. 1982. Total Carbon, Organic Carbon and Organic Matter In: A. L. Page, R. M. Miller and D. R. Keeney, eds. Methods of Soil Analysis Part 2 (2nd edition) Chemical and Microbiological Properties, Monograph No. 9, ASA-SSSA, Inc., Madison, WI, USA, p. 539-580.

Neupane, R. P., Sharma, K. R. and Thapa, G. B. 2001. Adoption of Agro-forestry in the Hills of Nepal: A Logistic Regression Analysis. Agricultural Systems, 72: 177-196.

Nuberg, I., George, B.H. and Reid, R. 2009. Agroforestry for Natural Resource Management. Australia: CSIRO Publishing.

Obeng, E.A. and Aguilar, F.X. 2015. Marginal Effects on Biodiversity, Carbon Sequestration and Nutrient Cycling of Transitions from Tropical Forests to Cacao Farming Systems. Agro-forestry Systems, 89:19-35.

Olsen, S.R. and Sommers, L.E. 1982. Phosphorous. In: A. L. Page, R. M. Miller and D. R. Keeney (Eds.), Methods of Soil Analysis. Part 2 (2ndedition) Chemical and Microbiological Properties (pp. 403-416). American Soc. of Agron. Monograph No. 9, ASASSSA, Inc., Madison, WI, USA.

Pachauri, R.K. 2012. Climate Change and Agroforestry. In: P.K.R. Nair and D. Garrity (Eds.), Agro-forestry - The Future of Global Land Use (pp. 1316). Springer Science and Business Media.

Pandit, B.H., Neupane, R.P., Sitaula, B.K. and Bajracharya, R.M. 2012. Contribution of Small Scale Agro-forestry System to Carbon Pool and Fluxes in Middle Hills of Nepal: An Overview. Small-Scale Forestry, 12:475-487 DOI 10.1007/ s11842-012-9224-0 publ.
Pandit, B.H., Shrestha, K.K. and Bhattarai, S.S. 2014. Sustainable Local Livelihoods through Enhancing Agro-forestry Systems in Nepal. Journal of Forest and Livelihood, 12(1):47-63.

Pearson, T.R.H, Brown, S. L. and Birdsey, R. A. 2007. Measurement Guidelines for the Sequestration of Forest Carbon, USDA Forest Service, 47p.

Ramesh, T., Manjaiah, K.M., Tomar, J.M.S. and Ngachan, S.V. 2013. Effect of Multipurpose Tree Species on Soil Fertility and $\mathrm{CO}_{2}$ Efflux underHilly Ecosystems of Northeast India. Agro-forestry Systems, 87:1377-1388.

Ranabhat, S., Awasthi, K.D. and Malla. R. 2000. Carbon Sequestration Potential of Alnus Nepalensis in the Mid Hill of Nepal: A Case Study from Kaski District. BankoJanakari, 18(2): 3-9.

Regmi, B.M. 2003. Contribution of Agro-forestry for Rural Livelihoods: A Case of Dhading District, Nepal. Paper Presented at The International Conference on Rural Livelihoods, Forests and Biodiversity, 19-23. May 2003, Bonn, Germany.

Rhodes, J.D. 1982. Cation Exchange Capacity. In: A. L. Page, R. M. Miller and D. R. Keeney (Eds.), Methods of Soil Analysis Part 2 (2 ${ }^{\text {nd }}$ Edition) Chemical and Microbiological Properties (pp. 149-158). American Soc. of Agron. Monograph No. 9, ASA-SSSA, Inc., Madison, WI, USA.

Shrestha, B.M., Sitaula, B.K., Singh, B.R. and Bajracharya, R.M. 2004. Soil Organic Carbon Stocks in Soil Aggregates Under Different Land Use Systems in Nepal. Agro-ecosystems, 70(2): 201213.

Synnot, P. 2012. Climate Change, Agriculture and Food Security in Nepal - Developing Adaptation Strategies and Cultivating Resilience. Mercy Corps Nepal.

Tacio, H.D. 1993. Sloping Agricultural Land Technology: A Sustainable Agro-forestry Scheme for the Uplands. Agro-forestry Systems, 22(2):145152.

The Glacier Trust. 2011. Forest, Agro-forestry and Slope Stability. In: R. Garton, Climate Change and Development in the Mountains of Nepal (p. 24).

Thorne, P.J. and Tanner, J.C. 2002. Livestock and Nutrient Cycling in Crop-Animal Systems in Asia. Agricultural Systems, 71: 111-126.

Yadav, R.S., Yadav, B.L., Chhipa, B.R., Dhyani S.K. and Ram, M.2010. Soil Biological Properties Under Different Tree Based Traditional Agroforestry Systems in Semi-Arid Region of Rajasthan, India. Agro-forestry Systems, 81:195-202.

Zomer, R.J., Bossio, D.A., Trabucco, A., Yuanjie, L., Gupta, D.C. and Singh, V.P. 2007. Trees and Water: Smallholder Agro-forestry on Irrigated Lands in Northern India. IWMI Research Report, 122. 